\title{
TITLE:
}

\section{Cytokine Gene Therapy for Myocarditis by in Vivo Electroporation(Abstract_要旨)}

$\operatorname{AUTHOR}(S)$ :

Nakano, Atsushi

\section{CITATION:}

Nakano, Atsushi. Cytokine Gene Therapy for Myocarditis by in Vivo Electroporation. 京都 大学, 2001, 博士(医学)

ISSUE DATE:

2001-11-26

URL:

http://hdl.handle.net/2433/150195

RIGHT: 


\begin{tabular}{|c|c|}
\hline 氏 & $\begin{array}{lll}\text { なか } & 9 & \text { あつし } \\
\text { 中 } & \text { 野 } & \text { 敦 }\end{array}$ \\
\hline 学位(専攻分野) & 士（医 \\
\hline 学 位 記 番 号 & 医 博 第 2415 号 \\
\hline 学位授与の日付 & 平成 13 年 11 月 26 日 \\
\hline 学位授与の要件 & 学位規則第 4 条第 1 項該 当 \\
\hline 研究科 · 専攻 & 医学研究科内科系専攻 \\
\hline 学位論文題目 & $\begin{array}{l}\text { Cytokine Gene Therapy for Myocarditis by in Vivo Electroporation } \\
\text { (In vivo 電気穿孔法をもちいた心筋炎のサイトカイン治療) }\end{array}$ \\
\hline
\end{tabular}

論文調査委員教 授中尾一和教 授米田正始教授千葉勉

論文 内容の要旨

心筋炎を含む各種の心疾患の病態に IL $-1 \beta, \mathrm{TNF}-\alpha$ などの炎症性サイトカインが深く関与することが明らかとなってい る。これまでのデータから推察されることは, 炎症性サイトカインは, 単に心筋において陰性変力作用, 細胞肥大作用等を 示すのみならず，NF-ィB などの転写因子を介して炎症性サイトカインが炎症性サイトカインを誘導するという positive feedback loop を形成し，生体に不利な反応を持続・増強させる悪循環を形成しているということである。すなわち心筋傷 害に引き続く心不全の発症には, 原因疾患に関わらず共通の炎症類似反応が関与していること, さらにこの悪循環を仲介す るサイトカインの抑制は心不全の治療につながることが示唆される。

ところが, 従来のリコンビナント蛋白投与を用いる方法はその蛋白導入の煩雑さ・費用等により限界があった。そこで申 請者らは安全・簡便・安価な方法として注目されている in vivo 電気穿孔法を用いて，抑制性のサイトカインである Interleukin-1 receptor antagonist（IL-1ra），IL-10，viral IL-10（vIL-10）の三種によるマウス心筋炎モデルの抗サイトカイ ン遺伝子治療を試みた。

$\mathrm{DBA} / 2$ マウス 4 週齢雄に脑心筋炎ウイルス接種ののち, 各遺伝子を導入した。心筋炎モデルでは血中 IL - $1 \mathrm{ra}$ 濃度が $5 \mathrm{ng} / \mathrm{ml}$ まで上昇したが, IL-1 $\mathrm{ra}$ 導入によりさらに $10.5 \mathrm{ng} / \mathrm{ml}$ にまで上昇した。IL-1 ra 導入群では空べクターを導入し たコントロール群に比して, 心筋炎による生存率が有意に改善した。また, vIL-10 導入群においても改善が認められた $(\mathrm{p}<0.005)$ 。心筋組織所見は, マッソントリクローム染色した画像から炎症細胞浸潤面積と全心筋面積を求めてその比を スコア化して比較した。 5 日目の心筋組織では, IL-1ra 導入群と vIL-10 導入群に扔いて, 空ベク夕一導入群に比して有 意な改善をみとめた。さらにその効果の機序を検討するために心筇における各種サイトカインの発現を real time PCR 法で 比較したところ, IL-1ra 導入群では TNF- $\alpha$ および iNOS の発現が有意に抑制されていた。また vIL-10 導入群では IFN ー $\gamma$ および iNOS の発現が有意に抑制されていた。したがって, IL-1ra および vIL-10 導入による治療は, いずれも心筋内 の炎症性サイトカインを抑制していることが治療効果につながっていることが示唆された。

以上の結果から，抑制性のサイトカインである IL-1 ra 拉よび yIL-10 により心筋炎モデルの治療が可能であることが示 唆される。IL-1 raは IL-1 ファミリーの第三のサイトカインで, IL-1 受容体に結合するものの細胞内にシグナルは伝達し ない。本検討でも認めたが, IL-1ra はマクロファージの TNF- $\alpha$ 産生を強く抑制することが知られており，またiNOS も マクロファージが主な産生源であることから，IL-1 ra による治療効果はマクロファージを標的としている可能性がある。 一方，vIL-10 は EB ウイルスがコードする hIL-10 類似の異種性の蛋白である。IL-10のもつ免疫抑制作用を有しつつ, IL-10の免疫刺激作用は持たないことから, 優れた免疫抑制効果を発揮するものとして期待される。炎症性サイトカイン の発現は原因疾患によらず心不全期に認められる共通の反応であることから, 本法を用いた遺伝子治療により，心疾患に対 する抗サイトカイン療法という新たな概念の治療法が期待される。 


\section{論文審査 の 結 果 の 要 旨}

心筋炎を含め, 心筋傷害に引き続く心不全の発症には, 原因疾患に関わらず共通の炎症類似反応が関与していることが明 らかとなり，この悪循環を仲介するサイトカインの抑制は心不全の治療につながることが示唆されている。ところが, 従来 のリコンビナント蛋白投与を用いる方法は投与方法に限界があった。そこで申請者らは in vivo 電気穿孔法を用いて，抑制 性のサイトカインであるIL-1 レセプターアンタゴニスト（IL-1ra），IL-10， viral IL-10（vIL-10）によるマウス心筋炎 モデルの抗サイトカイン遺伝子治療を試みた。

これら 3 種を心筋炎マウスに導入したところ, IL-1ra 導入群, vIL-10 導入群において急性期生存率の改善を認めた。 IL-1ra 導入群と vIL-10 導入群のマウスにおいて, 空ベクター導入群に比して有意な組織像の改善と心筋におけるいくつ かのサイトカインの発現が抑制されていたことから，いずれも心筋内の炎症性サイトカインを抑制していることが治療効果 につながっていることが示唆された。

以上の結果から，IL-1ra，vIL-10 な゙の抑制性サイトカインにより心筋炎モデルの治療が可能であることが示唆される。 炎症性サイトカインの発現は原因疾患によらず心不全期に認められる共通の反応であることから, 本法を用いた遺伝子治療 により，心疾患に対する抗サイトカイン療法という新たな概念の治療法が期待される。

以上の研究は, 心疾患におけるサイトカインの役割の解明に貢献し, 循環器病学に寄与するところが多い。従って本論文 は博士 (医学) の学位論文として価値あるものと認める。なお, 本学位授与申請者は, 平成13年10月 5 日実施の論文内容と それに関連した試問を受け，合格と認められたものである。 